\title{
Covid-19: Nightingale hospitals set to shut down after seeing few patients
}

\author{
Michael Day
}

London, UK

The mothballing of Britain's Nightingale hospitals, some of which have yet to treat a single covid-19 patient, has raised questions about whether resources to fight the pandemic were disproportionately focused on building intensive care capacity. Five emergency hospitals, with the capacity to treat almost 10 000 covid-19 cases, were opened last month at sites across the country $^{1}$ for fear the NHS might be overwhelmed following scenes of northern Italian intensive care units swamped with seriously ill patients.

But such high demand for intensive care never materialised. Just 51 patients have been treated at the 4000 bed medical facility situated in the refurbished Excel Centre in London's Docklands since it opened. Nightingale units in Birmingham and Harrogate have not treated a single patient, while a facility in Manchester has had just a handful of admissions.

Charles Knight, the chief executive of Nightingale London, announced on 4 May that no more covid-19 patients were likely to be admitted to the facility. "As a result, after the last patient leaves, the hospital will be placed on standby, ready to resume operations as needed, in line with others around the country," he said in a statement.

But some doctors have questioned the need for so much extra capacity.

One consultant, who works in mental health at a London teaching hospital and wanted to remain anonymous, said, "Was it a disproportionate use of funding and resources, given what's happened in care homes, dementia wards, and prisons? The Nightingale hospitals might have been done for the best reasons, but there's a danger that they're going to be seen as white elephants."

Richard Sullivan, director of the Institute of Cancer Policy at King's College London, said that the government and senior NHS officials had overreacted to the media coverage of scenes in Italian hospitals and had been unduly swayed by "simplistic" modelling of the pandemic.

"The Italian doctors were intubating far too many people. That would not have happened in British intensive care units," he said. "The trouble is that Neil Ferguson's modelling was wildly exaggerated. You cannot rely on a model to predict what happens with a pandemic. There are too many variables.

"You need good local intelligence to work out what transmissions rates really are; this did not appear to have happened."
Earlier projections by Ferguson of Imperial College on swine flu in 2009, and BSE in 2001, were wide of the mark. On 5 May Ferguson resigned from his position on the government scientific panel that advises ministers on covid-19, after it emerged he had contradicted his own advice on social distancing.

Chris Whitty, the chief medical officer for England, defended the extra capacity the NHS built, saying that had the government not taken these measures and hospitals were overwhelmed with cases it would also have been criticised.

It is unclear whether NHS England plans to use the Nightingale units to help hospitals restore some of their other services, such as elective surgery, that have been severely impeded by the lockdown.

The BMJ understands, however, that there are ongoing discussions between Barts Health Trust, which has managed the Nightingale at the Excel, and the NHS over how the facility might be repurposed, at least in part, in a capacity other than a giant intensive care unit.

But the Department of Health and Social Care has stipulated that the Nightingale hospitals must be able to resume some of their intensive care capability with 48 hours notice, in case there is a new surge of covid-19 cases when social distancing is relaxed or seasonal changes alter infection rates. "The department is concerned about the seasonal element of covid-19 and it fears a new surge in cases come October or November," said a source.

A spokesperson for the Nightingale hospitals told The BMJ, "The whole point of the Nightingales has been to build extra capacity to help local hospitals ensure all those who need care can get it, and it will be a mark of success if they continue not to operate at full capacity, because that will mean that the rest of the NHS has managed well and because the public have helped slow the spread of the virus, meaning fewer people needing care and ultimately fewer people losing their lives.

"Over the coming months, the Nightingales will still have a role to play supporting the NHS, based on what local clinical leaders think will best complement other care available in the region in meeting the needs of their communities."

\footnotetext{
1 Rimmer A. Sixty seconds on ... nightingales. BMJ 2020;368:m1290. 10.1136/bmj.m1290 32229514
}

Published by the BMJ Publishing Group Limited. For permission to use (where not already granted under a licence) please go to http://group.bmj.com/group/rights-licensing/ permissions 
